\title{
Earnings Surprises and Stock Price Reactions of Quoted Companies in Nigeria
}

\author{
Malthus Timothy Ekpe ${ }^{1}$, Rosemary Obiageri Obasi ${ }^{1}$, Sadiq Rabiu Abdullahi ${ }^{2}$, Umar Aliyu Mustapha ${ }^{3}$ \& Norfadzilah \\ Rashid $^{3}$ \\ ${ }^{1}$ Department of Accounting, Benson Idahosa University, Benin City, Edo State, Nigeria \\ ${ }^{2}$ Department of Accounting, Faculty of Management Sciences, Bayero University, Kano, Nigeria \\ ${ }^{3}$ Faculty of Business \& Management Science, Universiti Sultan Zainal Abidin, Terengganu, Malaysia \\ Correspondence: Norfadzilah Rashid, Faculty of Business \& Management Science, Universiti Sultan Zainal Abidin, \\ Terengganu, Malaysia.
}

Received: January 14, 2020

Accepted: April 26, 2020

Online Published: July 7, 2020

doi:10.5430/ijfr.v11n4p306

URL: https://doi.org/10.5430/ijfr.v11n4p306

\begin{abstract}
This study focuses on examining the relationship between stock prices and earnings surprises in quoted companies of Nigeria. This study applied a longitudinal research design which studies the effect of earnings surprises on stock prices using panel data. A sample of 64 companies was chosen to study in all sectors of the Nigerian Stock Exchange. The research data were obtained from secondary sources of the annual reports for the selected companies covering the period from 2013 to 2017. The measurement for earnings surprises used in the study is the residual or unexplained component of earnings persistence model commonly referred to as first-order autoregressive AR (1) regression of reported earnings. Were, the data analysis was carried out by regression using the generalised least squares technique. The regression results for positive earnings surprise shows that share prices react negatively to positive surprises with a coefficient of (-2.4109) in tandem with the return news hypothesis which suggests that positive earnings news results in a negative stock-price reaction. The negative earnings surprise results show that stock prices react positively to negative earnings surprises with a positive coefficient of $(0.1136)$. This is in line with the premise of return news, which indicates that negative earnings news leads to a positive reaction to the share price. The study recommends that there is a need to regulate the stock market to improve the level of market efficiency in stock markets. This will improve the rate at which earnings news will be reserved at stock prices. Secondly, there is a need to improve investor confidence in the disclosed profits made by companies.
\end{abstract}

Keywords: positive earnings surprise, negative earnings surprise, stock prices, market efficiency

\section{Introduction}

The Stock market reactions to earnings surprises were a significant concern among investors and company's managers. According to Kinney, Burgstahler and Martini (2002) profit surprises occur when the company's quarterly or annual earnings are above or below analysts' expectations. These analysts who work for a variety of financial companies and reporting agencies depend on their expectations on a variety of sources such as previous quarterly, annual reports, current market conditions in addition to the company's profit index. Earnings surprises can have a significant impact on a company's stock price.

Many studies indicate that a positive earnings surprise not only leads to an immediate rise in stock prices but also to a gradual increase over time see for instance (Mustapha, Rashid, Ado, Ademola, 2019). Sambharya (2011) indicated that stock markets tend to respond in the same direction as earnings surprises reacted to positive and negative even though a large proportion of earnings surprises lead to a stock market reaction in the opposite direction, which may be a response Act on other relevant information issued with the declaration of profits or the inaccurate measurement of the surprise earnings (Mustapha, Rashid, Ado, Ademola, 2020).

In an attempt to make accurate investment decisions, investors sometimes seek the advice of Professional Analysts to forecast future earnings of companies they wish to invest in. Such a forecast is heavily relied upon can impact positively or negatively on the company's stock prices. When the earnings estimate is above or fall below the actual earnings of the company, then Surprise has occurred (Lim, 2009). Majority of studies especially those in developed 
countries such as Kaestner (2005) Qiu (2014), Lim (2009); and Skinner and Sloan (2000) studied earnings Surprises and Stock returns using analyst estimates derived from a database system- Institution of Brokers Estimation System (IBES) and Compustat.

Thus, for developing countries like Nigeria is almost impossible to assess standardised analyst estimates. The fact that there is no standardised system of estimating earnings by analysts in Nigeria made this research very critical to any would-be investors. It should be of interest in how the share prices of companies respond to either positive or negative surprises. Meaning that any study that will bring the solution as regards accurate prediction of such surprises cannot be overemphasised. The practice of having to rely on trial and error judgement is not encouraging.

Studies conducted in Nigeria were mostly on stock prices and its determinants in the study of Malaolu, Ogbuabor and Orji (2013) they study stock prices and corporate characteristics while Adedoyin (2011) studied the stock prices and earnings announcements, Afego (2011) Capital market efficiency and effects of earnings announcement on stock prices as being reviewed. Another factor critical to the conduct of this research was the limitation in coverage of the previous studies done in Nigeria. Most of the studies like Adedoyin (2011); Afego (2011); Malaolu et al. (2013) focused on individual sectors of the economy, but this study focused on the entire sectors of the Nigerian Stock Exchange. Also the effect of globalisation occasioned by the event of 2008 and 2009 (Global Financial Meltdown) which impact negatively on the Nigerian investors. If investors were equipped with the knowledge of earnings surprise and how it could be derived will have helped in reducing the effect as they would have been able to predict companies' likely earnings outcome before making investment decisions.

Thus, the study aimed to examine the relationship between positive earnings surprise and stock prices, as well as to examine the relationship between negative earnings surprise and stock prices of listed companies in Nigeria. To achieve these objectives, these hypotheses were formulated:

$\mathrm{H}_{1}$ : Positive earnings surprise has no significant relationship with stock prices

$\mathrm{H}_{2}$. Negative earnings surprise has no significant relationship with stock prices

\section{Literature Review}

\subsection{Conceptualizing Earnings Surprises}

Earnings are one of the critical indicators of any business success as such forms the essential measure through which investors assess a business. In an attempt to predict these earnings to enable investors to make accurate investment decisions analysts and business managers come up with earnings forecast or estimates which sometimes fall below or above actual earnings of such organisations. Earnings Surprises occurred when the actual quarterly or annual earnings fall below or above forecast earnings (Lim, 2009).

Earnings surprises are also regarded as earnings news by some authors, Atiase, Supattarakul and Tse (2010) define earnings surprises as the difference between the actual quarterly earnings per share (EPS) and the average quarterly earnings forecast for individual analysts made within thirty days from the date of the previous quarter's earnings announcement, and discharged from the share price at the beginning of the current quarter. Companies are also classified as good news and bad news, good news when the surprise is positive and bad news when the surprise is negative. Lim (2009) identifies the earnings surprise as the difference between analyst estimates and reported earnings data. Hwang and Liu Luo (2014) define the earnings surprise as the difference between reported earnings per share (EPS) and analyst expectations set according to the late price.

According to Kinney, Burgstahler and Martini (2002), surprises in profits occur when a company reports quarterly or annual earnings above or below analysts' expectations. Fisher (2012) notes that the earnings surprise in accounting is the difference between the reported earnings and the unexpected profits of an entity. A surprise is an unexpected difference between the company's actual earnings per share and the expected earnings per share analyst. The overall positive earnings surprise means that the company performed better than expected in the last quarter. Often, a positive surprise is followed by a jump in the company's stock price once the market opens after the announcement. Earnings surprises are one of the reasons why earnings estimates are so attractive to investors. Sudden earnings, good or bad, can have a definite impact on individual stock performance and can often push specific stocks upward or meaningful downward (Nichols \& Wahlen, 2004).

\subsubsection{Stock Prices}

Stock prices have become one of the major indexes of measuring the performance of a company in the stock exchange market. The higher the prices of a company's share/stock, the more significant value investors placed on the company (Akinsulire, 2011). A stock/share is a unit of ownership in a company (Khatri, 2014). The share price is 
the price at which each of this unit of the ownership is sold (Akinsulire, 2011) while Geetha and Swaaminathan (2015) define it as the average price of the share derived from a company's financial year high or low. The share price is the closing market price per common share (Sindhu, Bukhari and Hussain, 2014). Stock price changes occur as a result of so many factors among which are- market equilibrium, i.e. demand for stock equal to the supply of stock, increases or decreases in supply (investor sentiments; expectations), increases in supply (corporate finance; share buybacks, secondary offerings, stock splits). On the other hand, considering the various valuation models, stock price changes can occur due to changes in dividends, changes in dividend growth rates, changes in the applicable discount rate (Geetha and Swaminathan 2015). Several factors, internal and external influence stock prices just like other commodity prices. These factors if considered adequately by organisations can lead to an increase in the value of a company, thereby building investor's confidence.

\subsubsection{Types of Earnings Surprises}

Negative earnings surprises

A negative surprise occurs when actual earnings fall short of analyst expectations. This means that the analyst overestimated the company's performance, and for specific reasons, the company's performance was less than expected. A surprise negative earnings for a particular company can destroy the company's stock price and may lead to a downward trend that can continue for an extended period.

\section{Positive Earnings Surprise}

Positive earnings or good news happen when actual earnings exceed analyst estimates. Abraham and Harrington (2016) identified forecasters with positive earnings surprises - sales whose growth may be related to continued earnings, cash flow, type of industry and analyst coverage. Positive earnings have the potential to increase investor expectations for the company's future profitability. It indicates that the organisation has crossed the profit threshold level. Surprising positive earnings act as a signalling device that a company has taken more positive action on investing in new products, advertising and promotion, as well as market penetration. Positive earnings surprises indicate a situation where current earnings exceed analyst expectations. In this case, the company's earnings outperformed the analyst's expectation (Nichols \& Wahlen, 2004).

\subsection{Empirical Review}

Sean (2009) studied the voluntary disclosure behaviour of high-tech companies suffering from bad economic news. Using a sample of 100 companies randomly chosen with negative returns, but not necessarily negative earnings surprises. The results show that the positive relationship between earnings surprises and voluntary disclosures is not present in this setting where negative stock returns are controlled, but (2) companies that have negative earnings surprises issue forward-looking statements with more negative information content - but only when conditioned by the size of the company or opportunities the growth.

Ertimure, Livnat and Martinikainen (2010) found in their study that investors react more strongly with a surprise of more than 1 dollar in sales of cost savings. It also highlighted that investors react more strongly to the surprise of dollar sales in the case of growth companies than value companies. On the contrary, investors are indifferent between the dollar surprise in cost savings and the dollar surprise in sales of value companies compared to growth companies. We also show that market reactions to negative sales surprises coupled with positive profit surprises, i.e. where expenditure cuts dominate the sales shortfall, are positive for value firms but negative for growth firms.

Al-Zahrani and Sakirat (2009) discussed the stock price reaction to profit surprises. The authors examined the behaviour of the Saudi Stock Exchange (SSM) in response to earnings announcements that did not meet the expectations of analysts to examine market efficiency. SSM seems to ignore the positive news for the first five days; then reactions tend to be consolidating in the following weeks, indicating a post-earnings drift, or PEAD. Meanwhile, SSM responded to the negative news in the first five days and then reversed and reported an upward trend after the earnings announcement. The individual-dominated market, coupled with the lack of analyst expectations is the primary explanation for this lack of reaction to positive news and the overreaction to negative news.

Abraham and Harrington (2016) study identify positive earnings surprises at different levels of profit surprises under strong and weak business conditions from 2010-2014. It measures the impact on surprises of a unique and diverse group of forecasters such as analyst coverage and the type of industry that is the safety, sales and cash flow characteristics that flow from financial statements. The study employs technology stocks that were found on the Nasdaq Stock Exchange, where these shares recorded a surprise of high positive profits. 
Event studies have been used to measure abnormal return and abnormal volume in declaring profits, while multiple regressions have tested the effect of forecasters with positive earnings surprises, including several analysts. A number of analysts highly anticipated positive earnings surprises of $\langle 20 \%, 21 \%-30 \%, 31 \%-100 \%$ and $\rangle 100 \%$ regardless of business condition. Cash flow showed positive earnings surprises within the scope of profit surprises by $21 \%-30 \%$ due to weak business conditions.

In a study on the industrial effects of information in the banking sector, Prokopczuk (2010) uses a negative earnings surprise to demonstrate how the share price impact of negative corporate information can affect competitors in the banking sector. He found a contagious effect in the surprising news of negative earnings in the banking sector (but not in the non-banking sectors). Johnson and Zhao (2006) studied distributing dividends to significant quarterly profit surprises, where the criterion for a profit surprise is the expected consensus. The authors document a noticeable similarity in the cross-sectional distribution of stock dividends in the period of announcing extreme negative surprises, and zero ("no") surprises. This finding is consistent with previous research on the limited explanatory power of the unforeseen earnings of stock returns during the reporting period. The authors then provide evidence of the degree to which different accounting and non-accounting factors contribute to a sectoral variation in the share price response to extreme earnings surprises and have shown that the differences between sectors in the stock price reaction to extreme earnings surprises do not correlate with advertising erosion profits.

Yu and Webb (2013) stated that Earnings Surprise news had been long found positively correlated with stock price movement around announcement days. Furthermore, that analyst has also been found to modify their future earnings forecasts after corporate earnings announcements as they finished digesting the new information. In most cases, researchers used earnings surprises and earnings announcements interchangeably as one always leads to the other. Hwang, Liu and Lou (2014) found stock recommendations significantly and positively predict subsequent earnings surprises, as well as narrow beats versus narrow misses.

Qiu (2014) shows that abnormal returns are affected by change guidance and magnitude of earnings surprises and to a lesser degree, the number of analyst covering the stock. He can divide the companies based on positive and negative earnings surprises and found that Standardized Unexpected Earnings is a better variable for measuring abnormal returns than the usual unexpected earnings used in the literature. Wang and Phet (2012) discovered that stock behaviours are gradually responding to a dividend announcement and that the effect of positive earnings surprises on stock prices continues longer than a negative earnings surprise. Lim (2009) found that negative surprises tend to have more significant impacts than positive surprises. This means that investors interact with negative surprises more than they do with positive surprises.

\subsection{Theoretical Review}

\subsubsection{Prospects/Loss Aversion Theory}

Amos and Kahnemen (1981) developed this theory. People express different levels of emotion towards gains rather than losses. Individuals are exposed to more stress or feeling dissatisfied when they face potential losses than they are happy when they face equal gains. This theory explains the reasons why investors own some stocks despite the loss; that people take more risk to prevent losses from making gains. This makes investors remain in a precarious stock position, hoping that the price will bounce back. The reluctance theory makes the loss for another reason the reason why investors choose to hold down losing stocks and sell competing shares, believing that the losers will outperform the winners in the coming period. This money or fund flows into higher-performing stocks or mutual funds more than poor-performing stocks. The theory explains that as investors interact more with positive profit surprises compared to negative earnings surprises.

\subsubsection{Over/Under-reacting Theory}

This is an extension of probability theory as developed by Amos and Kahnmen (1981). The theory states that investors are overly optimistic when the market price of shares rises, assuming that they will continue. On the other hand, they tend to be overly pessimistic when the opposite is the case when contraction occurs. The result of placing much importance on current events and ignoring historical events is an overreaction or reaction to market events that usually lead to a significant price drop due to the announcement of profits on bad news and a significant increase after announcing good news. When investors are over-optimistic, this optimism exceeds stocks in their real or genuine terms. The theory explains that as investors interact more with positive profit surprises than negative ones.

\subsubsection{Efficient Market Hypotheses}

It confirms the efficiency of financial markets where the published information is known. It is a market in which stock prices reflect essential information about companies. This theory was developed by Fama (1965). He stressed 
that the type of information available at any time determines the values of shares and that the market for safety values will become active if the necessary information is available to other investors. Based on the rational expectation theory (RET), it is also believed that the stock or bond price depends on what potential sellers and sellers believe shortly. This theory is what leads to the random walk theory or the valid market theory of stock prices as defined by Malaolu, Ogbuabor, and Orji (2013). They also assumed that practical market theory of stock prices uses the concept of rational expectations to infer that investors are buying stocks that they expect to have above-average returns

\section{Methodology}

This study applied a longitudinal research design; studies the effect of profit surprises on stock prices using plate data. A sample of 64 companies was chosen to study in all sectors of the Nigerian Stock Exchange. The research data were obtained mainly from secondary sources, which are the annual reports of the selected companies that covered the period from 2013 to 2017. The measure of profit surprises used in the study is the remaining or unjustified component of profit continuity (PER) a model usually referred to as the first automatic bounce (1) Decreased reported profits. Kothari (2001) claims that the main advantage of the cross-section approach overestimating time series is that cross-section models provide statistical strength without imposing a strict surviving bias.

The profit model (1) is first estimated to derive the expected values of profits, then the expected values and the difference in profits prepared to generate the residual or unjustified component of profits are retracted, which is a measure of surprise. Consequently, the earnings surprise is seen as the expected error from AR (1) using the fitted profit values. To estimate the models, the method for analysing the data used in this study is to analyse plate regression using the generalised least squares technique.

\subsection{Model Specification}

The model for this study is based on the work of Fama and French (2000) in the study: Predicting Profitability and Profits, Kothari et al. (2005), Frankel and Litov (2009), Kama (2009) In studying the market reaction to revenue and profit surprises, job specifications were provided for the form below:

Following Kothari et al. (2005) earnings surprise is defined as the residual of an ar (1) model;

$$
\mathrm{ESUR}=f \text { (Residual of } \operatorname{ar}(1) \text { earnings model) }
$$

Using EPS, we derive the ar(1) earnings, model

$$
\mathrm{EPS}=f\left(\mathrm{EPS}_{(-1)}\right)
$$

$\mathrm{EPS}_{\mathrm{it}}=\lambda_{0}+\lambda_{0} \quad \mathrm{EPS}_{(-1)}+\mu_{\mathrm{it}}$

Where $\mu_{\mathrm{it}}=$ residual series of the ar (1) model

$$
\mathrm{ESUR}=f \text { (forecast error of ar (1) earnings model) }
$$

Using EPS, we derive the forecast error ar (1) earnings, model

$$
\mathrm{f} \mu_{\mathrm{it}}=\mathrm{EPSF}_{\mathrm{it}}-\lambda_{0}-\lambda_{1} \operatorname{EPS}(-1)
$$

Where $\mathrm{f} \mu_{\mathrm{it}}=$ forecast error of the ar (1) model

$\mathrm{EPSF}=$ Forecast EPS series

$$
\mathrm{SP}=f(\text { ESUR, POS_ESUR, NEG_ESUR })
$$

Specifying the econometric model, it becomes;

$$
\mathrm{SP}_{\mathrm{it}}=\alpha_{0}+\beta_{1} \mathrm{ESUR}_{\mathrm{it}}+\beta_{2} \mathrm{POS}_{-} \mathrm{ESUR}_{\mathrm{it}}+\beta_{3} \mathrm{NEG} \_E S U R_{\mathrm{it}}+\mathrm{u}_{\mathrm{it}}
$$

Where

$\mathrm{SP}_{\mathrm{it}}=$ Share price of the firm $\mathrm{i}$ and time $\mathrm{t}_{\mathrm{i}}$

ESUR $=$ Earnings surprise of firm $\mathrm{i}$ and time $\mathrm{t}_{0}$

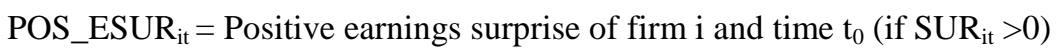

NEG_ESUR ${ }_{\mathrm{it}}=$ negative earnings surprise of firm $i$ and time $t_{0}$ (if SUR $<0$ ) 


\section{The Results}

Table 1. Descriptive statistics

\begin{tabular}{lllll}
\hline & SP & FORESUR & ESUR & EPS \\
\hline Mean & 14.687 & $5.31 \mathrm{E}-05$ & -0.039123 & 1.005745 \\
\hline Median & 6.010 & -0.004542 & -0.333432 & 0.430000 \\
\hline Maximum & 215.560 & 0.850230 & 10.44076 & 13.57000 \\
\hline Minimum & 4.000 & -0.058537 & -6.155612 & 0.00000 \\
\hline Std. Dev. & 26.648 & 0.064652 & 1.751356 & 1.923104 \\
\hline Skewness & 4.201 & 11.49754 & 2.019925 & 2.786202 \\
\hline Kurtosis & 24.531 & 145.2866 & 16.49037 & 15.97883 \\
\hline Jarque-Bera & 4763.091 & 185237.1 & 1768.269 & 1778.891 \\
\hline Probability & 0.000 & 0.000000 & 0.000000 & 0.000000
\end{tabular}

Source: Researcher's compilation (2018)

Descriptive statistics for the variables indicate that the share price (SP) has an average of 14.68 and a standard deviation of 26.648 while the maximum and minimum values are 215.56 and 4.00 , respectively. The averaged is at 0.0000531 with a standard deviation of 0.0646 while the maximum and minimum values are 0.850 and -0.0585 , respectively. ESUR has a mean of -0.039 and a standard deviation of 1.7513 with the maximum and minimum values of 10. 441 and -6.155 , respectively. For EPS returns $=1.00$ and the standard deviation is 1.923 max and minimum values 13.57 and 0.00 respectively. Jarque-Bera statistics and p-values for all variables indicate an unexpected presence in the extreme values in the data series.

Table 2. Correlation statistics

\begin{tabular}{lllll}
\hline & SP & FORSUR & ESUR & EPS \\
\hline SP & 1 & 0.02239 & 0.07525 & 0.30788 \\
\hline FORSUR & 0.02239 & 1 & 0.12703 & 0.10806 \\
\hline ESUR & 0.07525 & 0.1270 & 1 & -0.00742 \\
\hline EPS & 0.30788 & 0.10806 & -0.00742 & 1 \\
\hline
\end{tabular}

Source: Researcher's compilation (2018)

From Table 2 above, correlation coefficients for variables are examined. As noted, the following correlation exists between SP \& FORSUR $(r=0.022)$, SP \& ESUR $(r=0.0753)$, SP \& EPS $(r=0.308)$. A positive parameter indicates that increases in these variables can be linked to an increase in stock prices and vice versa. Although correlation analysis is limited for inferential purposes because it does not refer to the causal relationship or functional dependence in the strict sense of the word, regression analysis is most appropriate for this purpose. The result also indicates that multicollinearity presence is unlikely given the correlations between explanatory variables are low.

Table 3. Earnings surprises and share price

\begin{tabular}{llll}
\hline Variable & Predicted & Dependent variable: & $S P$ \\
& Sign & $\begin{array}{l}\text { Earnings surprise } \\
\{+v e\}\end{array}$ & $\begin{array}{l}\text { Earnings surprise } \\
\{-v e\}\end{array}$ \\
\hline $\mathrm{C}$ & 20.2587 & 9.0072 \\
& $(9.62304)$ & $(3.3953)$ \\
& $\{0.0398\}$ & $\{0.0089\}$ \\
\hline
\end{tabular}




\begin{tabular}{lll}
\hline ESUR & -2.4109 & 0.1136 \\
& $(1.7327)$ & $(1.0753)$ \\
& $\{0.1696\}$ & $\{0.9160\}$ \\
\hline ESUR(-1) & 3.4580 & -1.5260 \\
& $(1.7550)$ & $(1.5785)$ \\
& $\{0.0538\}$ & $\{0.3352\}$ \\
\hline ESUR(-2) & 1.0178 & -0.0966 \\
& $(1.7324)$ & $(1.3743)$ \\
\hline ESUR(-3) & $\{0.5592\}$ & $\{0.9441\}$ \\
\hline ESUR(-4) & $3.6449 *$ & -1.14057 \\
& $(1.64701)$ & $(0.9536)$ \\
& $\{0.0310\}$ & $\{0.2336\}$ \\
\hline AR(1) & -2.5436 & 0.1841 \\
& $(1.6707)$ & $(0.7848)$ \\
& $\{0.1335\}$ & $\{0.8149\}$ \\
\hline AR(2) & 0.6778 & 0.91549 \\
& $(0.1301)$ & $(0.2716)$ \\
\hline Prstatistics & $\{0.0000\}$ & $\{0.0010\}$ \\
\hline Model parameters & -0.1569 & -0.45383 \\
\hline R.W stat & $(0.1312)$ & $(0.1995)$ \\
& $\{0.2366\}$ & $\{0.0243\}$ \\
\hline
\end{tabular}

Source: Researcher's compilation (2017)

Table 3 above shows the regression result of the contemporary relationship between positive/negative surprises and stock prices. The regression results for the positive earnings surprise show the model properties with the coefficient of determination (R2) and Adj R2 from 0.449 and 0.389, respectively. These values indicate that the model only explains about $44.9 \%$ of the systematic changes in equity prices with a modified $38.9 \%$. F-stat $(6.539)$ and $p(0.00)$ indicate acceptance of the hypothesis of a long linear relationship between variables (independent and independent) at a level of $5 \%$ of significance while statistics of DW 2.040 indicate that a serial relationship exists in the tailings is unlikely. The results reveal that stock prices interact negatively with positive surprises by a factor of (-2.4109) along with the hypothesis of returns news, which indicates that positive earnings news leads to a negative reaction to stock prices. Therefore, the relationship between gross earnings news and contemporary returns must be strengthened (becoming more negative) when using an improved earnings news measure (due to the lower error component of the earnings news variable).

However, the stock price response is not significant, at $5 \%$. The coefficients of lag earning variables $(1,2$ and 4$)$ were all insignificant; $(3.458, \mathrm{p}=0.1843),(1.0178, \mathrm{p}=0.559),(-2.543,0.1335)$ while for lag 3 , the coefficient is positive and significant $(3.6449, \mathrm{p}=0.031)$ which suggest some delay in the response of stock price to positive earnings surprise. Hence, we accept the null hypotheses that positive earnings surprises have no significant impact on stock prices. The finding is in tandem with Geetha and Swaaminathan (2015), Malhotra and Tandon (2013). In contrast with Wang and Phet (2012) discovered that stock behaviour gradually responds to the earnings announcement and that the effect of positive earnings surprises on stock prices lasts longer than that of a negative earnings surprise. 
The regression results for the negative earnings surprise show the model properties with the coefficient of determination (R2) and Adj R2 at 0.523 and 0.5008 , respectively. These values indicate that the model only explains about $52.3 \%$ of systemic changes in stock prices with an added value of 50.08\%. F-stat (23.072) and p (0.00) indicate acceptance of the hypothesis of a long linear relationship between variables (independent and independent) at a level of $5 \%$ of significance while statistics of DW 1.81 indicate a serial relationship presence in waste is unlikely. The results reveal that share prices react positively to negative earnings surprises with a coefficient positive (0.1136). This is in tandem with the return news hypothesis, which suggests that negative earnings news results in a positive stock-price reaction. The coefficients of lag earning variables (1, 23 and 4) were all insignificant; $\operatorname{ESUR}_{(-1)}(-1.5260, \mathrm{p}=0.335)$ $\operatorname{ESUR}_{(-2)}(-0.0966, \mathrm{p}=0.9441), \operatorname{ESUR}_{(-3)}(-1.1406,0.2336)$ and $\operatorname{ESUR}_{(-4)}(0.1841, \mathrm{p}=0.815)$ and this suggest that there is no evidence on the aggregate of post-announcement drift in which prices react slowly to negative earnings surprises. Hence, we accept the null hypotheses that positive earnings surprises have no significant impact on stock prices. The finding is in tandem with Bonsall, Bozanic and Fischer (2013), Geetha and Swaaminathan (2015), Malhotra and Tandon (2013) though in contrast, AL-Shubiri (2010) Levine and Zervos (1998), Corwin (2003).

\section{Conclusion}

Earnings surprises and its effects on stock prices is an issue of concern to any would-be investor, Stock market reactions to earnings surprises have been a significant concern among investors and companies. It is important to note that stock prices changes will not be significant in relative to earnings surprises in a situation where the market is efficient. Given the fact that this study is suited mostly in the Nigerian environment, and none has ever existed; hence the research was conducted to examine the impact of earnings surprises on stock prices in Nigeria quoted companies.

The findings of the study reveal that share prices react negatively to positive surprises with a coefficient negative are in tandem with the return news hypothesis, which suggests that positive earnings news results in a negative stock-price reaction. The results reveal that share prices react positively to negative earnings surprises with a positive coefficient. This is in tandem with the return news hypothesis which suggests that negative earnings news results in a positive stock-price reaction. This research contributes to the emerging literature on earnings surprises by adopting the Autoregressive earnings model and forecast error in determining earnings surprises as this has been employed by a slight number of research examining quoted companies in Nigeria. Aside lack of standardised database system which resulted in a difference in the methodology adopted, investors in developing countries are poorly informed and unsophisticated. The presence of weak institutions and non-availability of research in this area dealing directly with stock prices and earnings surprises in Nigeria also make this research relevant.

The study recommends that there is need for stock market regulation to improve the level of market efficiency of the stock markets. This will improve the rate at which earnings news will be impounded into stock prices. Secondly, there is a need to improve investors' confidence in disclosed earnings made by companies. A situation where stock prices do not respond to earnings news for a developing country like Nigeria with evidence of near weak or semi-efficient status may suggest that investors are sceptical about disclosed earnings and this tend to maintain their positions than to react based on such news. Other studies should be conducted using different proxies of earnings surprise and also to apply it in diferent sample in order to proved the robustness of this study.

\section{References}

Abraham, R., \& Harrington, C. (2016). Predictors of the degree of positive earnings surprises. Open Journal of Accounting, 5, 25-34. https://doi.org/10.4236/ojacct.2016.53004

Adedoyin, A. O. (2011). Share price determination and corporate firm characteristics. Retrieved from www.theses.covenantuniversity.edu.ng/../share\%20price \%20Determination\%20A

Afego, P. (2011). Stock price response to earnings announcements: Evidence from the Nigerian stock market. Retrieved from https://mpra.ub.uni-muenchen.de/33931/

Akinsulire, O. (2011). Financial management. Nigeria: Ceemol Nig. Ltd.

Al-Shubiri, F. N. (2010). Analysis of the determinants of market stock price movements: An empirical study of Jordanian commercial banks. International Journal of Business and Management, 5(10), 137-147.

Alzahrani, A., \& Skerratt, L. (2009). How the market reacts to earnings announcements in the absence analysts and institutions evidence from Saudi market. Working paper, Department of Economics and Finance, Brunel University, West London. Retrieved from www.citeseerx.ist.psu.edu 
Amos, T., \& Kahneman, D. (1981). The framing of decisions and the psychology of choice. Science, New Series, 211(4481), 453-458.

Atiase, R., Li, H., Supattarakul, S., \& Tse, S. (2005). Market reaction to multiple contemporaneous earnings signals: earnings announcements and future earnings guidance. Review of Accounting Studies, 10(4), 497-525.

Corwin, S. A. (2003). The determinants of under-pricing for seasoned equity offer. Journal of Finance, 58(5), 2249-2279.

Ertimur, Y., Livnat, J., \& Martikainen, M. (2003). Differential market reactions to revenue and expense surprises. Review of Accounting Studies, 8, 185-211.

Fama, E. F. (1965). The behaviour of stock-market prices, Journal of Business, 38, 34-105.

Fama, E. F., \& French, K. R. (1997). Industry costs of equity. Journal of Financial Economics, 43, 153-193.

Fama, E. F., \& French, K. R. (2000). Forecasting profitability and earnings. The Journal of Business, 73(2), 161-175.

Fischer, D. (2012). Investor under-reaction to earnings surprises and overreaction to product news in the drug industry. Journal of Business and Economic Studies, 18, 82-90.

Frankel, R., \&Litov, L. (2009). Earnings persistence. Journal of Accounting and Economics, 47(1-2), 182-190. https://doi.org/10.1016/j.jacceco.2008.11.008

Geetha, E., \& Swaaminathan, T. M. (2015). A study on the factors influencing stock price: A comparative study of Automobile and Information Technology Industries stocks in India. International Journal of Current Research and Academic Review, 3(3), 97-109.

Hwang, H. B., Liu, B., \& Lou, D. (2014). Consistent earnings surprises. Retrieved from www.bhwang.com/a.../z.../consistent\%20earnings\%20surprises.pdf

Johnson, W. B., \& Zhao, R. (2006). Cross-sectional variation in the share price response to extreme earnings surprises. The University of Iowa, Iowa City, IA 52242. Retrieved from www.ibrarian.net/.../Cross_sectional_Variation_in_the_Share_Price_Resp.pdf

Kama, I. (2009). On the market reaction to revenue and earnings surprises. Journal of Business Finance \& Accounting, 36(1 \& 2), 31-50.

Kester, M. (2005). Anomalous price behaviour following earnings surprises: Does representativeness cause overreaction?. Retrieved from www.econwpa.repec.org/eps/fin/papers /0505/0505018.pdf

Khatri, D. (2014). Security analysis and portfolio management. Trinity- New Delhi: Laxmi Publications PVT Ltd.

Kinney, W., Burgstahler, D., \& Martini, R. (2002). Earnings surprise materiality as measured by stock returns. Journal of Accounting Research, 40, 1297-1329. https://doi.org/10.1111/1475-679X.t01-1-00055

Kothari, S. P. (2001). Capital markets research in accounting. Journal of Accounting and Economics, 31(1-3), 105-231.

Kothari, S. P., Lewellenb, J., \& Warnerd, J. B. (2005). Stock returns, aggregate earnings surprises, and behavioural finance. Journal of Financial Economics, 79, 537-568.

Levine, R., \& Zervos, S. (1998). Stock markets, banks, and economic growth. American Economic Review, 88, 537-558.

Lim, S. (2009). Assessing the effects of earnings surprise on returns and volatility with high-frequency data. Duke University Retrieved from https://econ.duke.edu/.../Sam\%20Lim\% 20Final\%20Formatted.pdf

Malaolu, V. A., Ogbuabor, J. E., \& Orji, A. (2013). Determinants of stock price movements in Nigeria: Evidence from monetary variables. Journal of Economics and Sustainable Development, 4(14).

Malhotra, N., \& Tandon, K (2013). Determinants of stock prices: Empirical evidence from NSE 100 companies international. Journal of Research in Management \& Technology (IJRMT), 3(3), 86-95.

Mustapha, U. A., Rashid, N., Ado, A. B., \& Ademola, L. S. (2019, November). The Effect of Audit Quality on Accruals Earnings Management in Nigerian Listed Firms. FI. International Journal of Recent Technology and Engineering (IJRTE). 
Mustapha, U. A., Rashid, N., Ado, A. B., \& Ademola, L. S. (2020, January). Development of Corporate Governance and the Effect of Corruption on the Nigerian Financial Institutions. Journal of Advanced Research in Dynamical \& Control Systems, 12(1). https://doi.org/10.5373/JARDCS/V12I1/20201003

Nichols, C., \& Wahlen, J. M. (2004). How do earnings numbers relate to stock returns? A review of classic accounting research with updated evidence. Accounting Horizons, 18(4), 263-286.

Nigerian Stock Exchange. (2015). Fact-book. NSE, Lagos, Nigeria.

Oludoyi, S. B. (1999). Capital market efficiency and the effects of earnings announcements on share prices in Nigeria. Unpublished PhD thesis, University of Ibadan, Nigeria.

Prokopczuk, M. (2010). Intra-industry contagion effects of earnings surprises in the banking sector. Applied

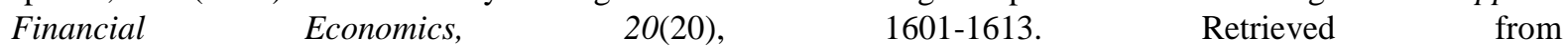
https://scholar.google.com/citations?user=QCOndUMAAAAJ\&hl=en

Qiu, L. (2014). Earnings announcement and abnormal return of S\&P 500 companies, Washington University in St. Louis Economics Department Honors Thesis. Retrieved from https://economics.wustl.edu/files/economics/.../luke_qiu_-_final.pdf

Rashid, N. M. N. N. M., Noor, R. M., Mastuki, N. A., \& Bardai, B. (2015, May). A longitudinal study of corporate tax planning: Analysis of companies' tax expense and financial ratios. Pertanika Journal of Social Science and Humanities, 23, 109-120.

Sambharya, R. B. (2011). Security analysts' earnings forecasts as a measure of firm performance: An empirical exploration of its domain. Management Decision, 49(7), 1160-1181.

Shon, J. (2009). Voluntary disclosures and earnings surprises: The case of high-tech firms in periods of bad economic news. Accounting and Taxation, 1(1), 133-143

Sindhu, M. I., Bukhari, H. M. S., \& Hussain, A. (2014). Macroeconomic factors do influencing stock price: A case study on Karachi stock exchange. Journal of Economics and Sustainable Development, 5(7), 2222-2855.

Skinner, D. J., \& Sloan, R. J. (2000). Earnings surprises, growth expectations, and stock returns. University of Michigan Business $\quad$ School. Retrieved from https://www.researchgate.net/.../257823174_Discussion_of_Earnings_Surprises_Growth_Expectations_and_Sto ck_Returns

Wang, C., \& Phet, G. K. (2012). Stock return performance around earnings announcements: Empirical evidence from Nordic Stock Market. Retrieved from www.divaportal.org/smash/get/diva2:538702/fulltext02

Yu, S., \& Webb, G. (2013). Earnings surprises, industry effects, and fair regulation disclosure. Montclair State University Department of Economics and Finance. Retrieved from https://mediacast.blob.core.windows.net/.../Faculty/.../swfa2014_submission_246.pdf 